Article

\title{
Alumina Porous Ceramics Obtained by Freeze Casting: Structure and Mechanical Behaviour under Compression
}

\author{
Dominique Hautcoeur ${ }^{1, *}$, Maurice Gonon ${ }^{2}$, Carmen Baudin ${ }^{3}$, Véronique Lardot ${ }^{1}$, \\ Anne Leriche ${ }^{4}$ and Francis Cambier ${ }^{1}$ (D) \\ 1 Belgian Ceramic Research Centre (BCRC), Avenue Gouverneur Cornez 4, B-7000 Mons, Belgium; \\ v.lardot@bcrc.be (V.L.); f.cambier@bcrc.be (F.C.) \\ 2 UMONS-Institut Matériaux-Rue de l’Epargne 56, B-7000 Mons, Belgium; \\ MauriceFrancois.GONON@umons.ac.be \\ 3 Instituto de Ceràmica y Vidrio, ICV-CSIC Kelsen 5, 28049 Madrid, Spain; cbaudin@icv.csic.es \\ 4 Laboratoire des Matériaux Céramiques et Procédés Associés (LMCPA), UVHC, Boulevard Charles de Gaulle, \\ F-59600 Maubeuge, France; anne.leriche@univ-valenciennes.fr \\ * Correspondence: d.hautcoeur@bcrc.be; Tel.: +32-6540-3474
}

Received: 18 April 2018; Accepted: 14 June 2018; Published: 20 June 2018

\begin{abstract}
The aim of the work is to analyse the mechanical behaviour of anisotropic porous alumina ceramics processed by freeze casting (ice templating). The freeze cast specimens were characterised by a lamellar structure with ellipsoidal pore shape, with a size ranging from 6 to $42 \mu \mathrm{m}$ and 13 to $300 \mu \mathrm{m}$ for the minor and major axes, respectively, as a function of the freezing rate and the powder and binder contents. The pore volume fraction ranged from 40 to 57\%. SEM analysis of the porous structures after the compression test showed a typical deformation pattern caused by the porosity gradient through the specimen, as determined by X-ray radiography. The apparent elastic modulus of the anisotropic porous alumina ranged from 0.2 to $14 \mathrm{GPa}$ and the compressive strength from 6 to $111 \mathrm{MPa}$, varying as a function of the process parameters which determine the pore network characteristics. The relationships between stress-strain behaviour in compression and the microstructure and texture were established. An analytical model based on a Gibson and Ashby relationship was used and adapted from SEM microstructural analysis after a mechanical test in order to predict the compressive strength of processed anisotropic alumina.
\end{abstract}

Keywords: freeze casting; ice templating; mechanical properties; strain mode; porosity gradient effect

\section{Introduction}

Porous ceramics are used for different applications such as catalyst supports [1], biocompatible scaffolds [2], piezoelectric supports [3], membranes [4], thermal insulation devices [5], electrodes for fuel cells [6], preforms for processing ceramic/metal composites [7] and so on. Specific characteristics of the porous structure (pore size distribution, permeability, chemical stability, structure control) are required depending on the application. The porous structure can be isotropic or anisotropic according to the shaping process used [8].

Freeze casting by ice templating has been used and developed for processing porous ceramics for more than forty years [9]. When an anisotropic freezing direction is applied, freeze casting consists of freezing a slurry of ceramic particles through a thermal gradient in order to create a unidirectional ice network [10-12]. During freezing, the ceramic particles are ejected above the ice crystals to form a stack of particles. After ice sublimation, a green body with an anisotropic porosity is obtained. One advantage of these anisotropic porous ceramics is their mechanical properties [13-15]. It has been 
shown that for similar porosity levels, freeze cast specimens have higher compressive strengths than isotropic porous ones [16].

Most of the time, uniaxial compression strength is used to characterise the mechanical behaviour of freeze-cast specimens [17-19], while some authors have applied simple analytical models for fitting the results $[20,21]$. Only a few studies have been carried out on the relationships between structure and mechanical properties $[22,23]$ and they are mainly focused on the porosity level or the freeze casting parameters, without taking into account the overall characteristics of the specimen. Recently, it has been shown that an adequate way to predict the compressive strength of freeze cast specimens is to use the models developed by Gibson and Ashby [24]. Different Gibson and Ashby models such as closed, open, and honeycomb cells have been considered and it has been shown that the best description of the experimental results is given by the honeycomb out-of-plane model [25].

This work aims at establishing the relation between the porosity and the compressive strength for freeze cast anisotropic porous alumina ceramics. In a previous work, it has been assumed that a porosity gradient through the specimen might impact the porous ceramic characteristics [26]. Indeed, a ceramic/metal composite processed from a freeze cast porous preform exhibits a variation of the thermal conductivity through the specimen height, which can be explained by a modification of the metal volume fraction induced by a porosity gradient. This characteristic was studied in this work and was linked with the strain behaviour of freeze cast specimens during compressive strength determination. An analytical model based on Gibson and Ashby, taking into account the macro and micro porosity, ref. [27] was used and adapted as a function of the characteristics of the deformation behaviour.

\section{Materials and Methods}

Alumina slurries with various powder and binder contents were prepared in deionized water with a small amount of ammonium polymethacrylate anionic dispersant (Dolapix CE64, from Zschimmer and Schwarz, Germany). Alumina powder (d50 0.4 $\mu \mathrm{m}$, specific surface area $=8 \mathrm{~m}^{2} \cdot \mathrm{g}^{-1}$, Rio Tinto Alcan, Brazil) contents ranging from 28 to 33 vol. \% were used. These contents were below the breakthrough concentration, which is around 56 vol. \% [28]. Slurries were ball milled for $24 \mathrm{~h}$ with alumina balls. After ball removing, polyethylene glycol ( $\mathrm{Mw}=1000 \mathrm{~mol} \cdot \mathrm{g}^{-1}$, from Merck, Germany) was added $(0<$ wt. $\%<6)$ as binder.

The mixed slurries were poured into a cylindrical TEFLON mould ( $30 \mathrm{~mm}$ inner diameter and $50 \mathrm{~mm}$ long) and placed on a freezing device. The mould was partially filled in order to avoid re-melting issues. Slow cooling rates of $1{ }^{\circ} \mathrm{C} \cdot \mathrm{min}^{-1}$ or $5{ }^{\circ} \mathrm{C} \cdot \mathrm{min}^{-1}$ were used with this device. A schematic illustration of the equipment is shown in Figure 1. For the rapid cooling rate of $20^{\circ} \mathrm{C} \cdot \mathrm{min}^{-1}$, a classic device $[29,30]$ was used with liquid nitrogen as cooling liquid. The frozen specimens were placed into a freeze dryer equipment (HETO CD8, Thermo Fisher Scientific, Waltham, MA, USA) for $48 \mathrm{~h}$ to remove ice at a pressure close to $10 \mathrm{~Pa}$. All green bodies were sintered during $2 \mathrm{~h}$ at $1600{ }^{\circ} \mathrm{C}$ using $5^{\circ} \mathrm{C} \cdot \mathrm{min}^{-1}$ as heating and cooling rates.

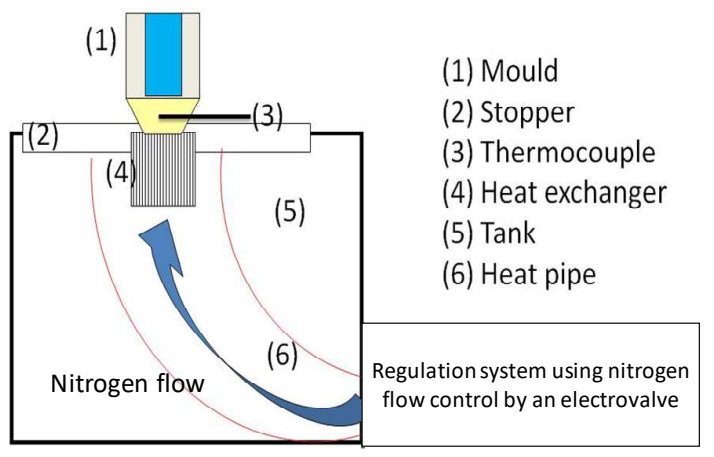

Figure 1. Schematic of the freeze casting device [26]. 
In order to understand the macroscopic properties of the specimens, two types of pores had to be considered. Figure 2 illustrates the structure of a specimen, perpendicular to the freezing direction. One can distinguish "large" macropores resulting from ice crystals and micropores within the ceramic walls.

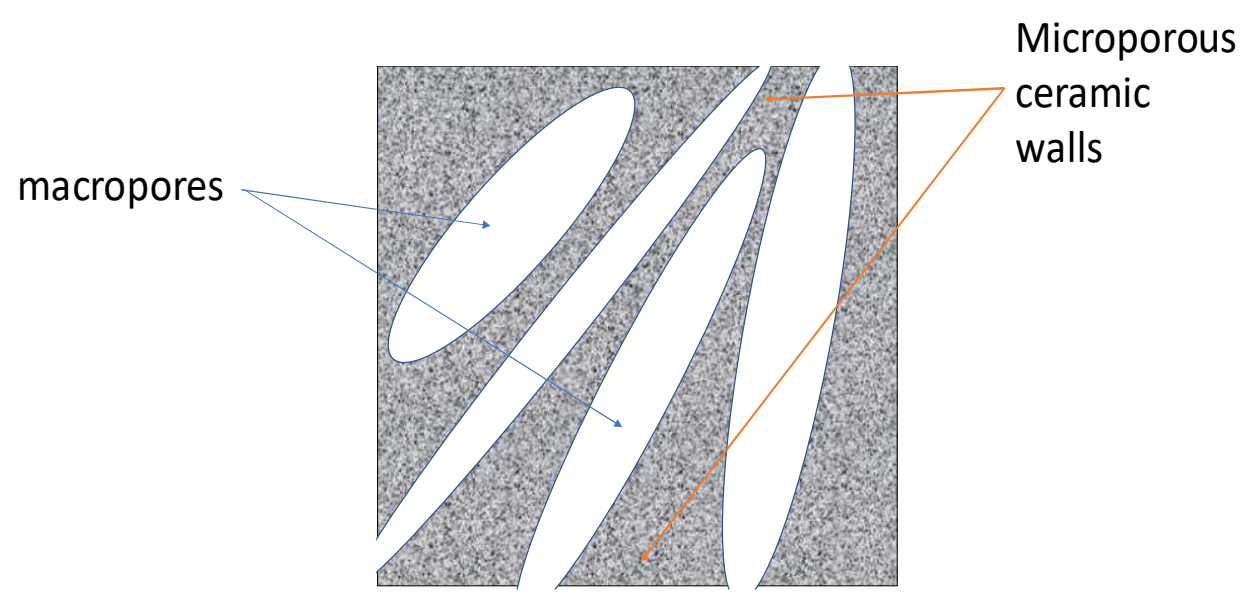

Figure 2. Schematic of macro and micropores.

Total porosity, $p$, the apparent density and bulk density were determined using Archimedes' method. Distilled water was used as the liquid medium. Porous specimens were kept under vacuum during $2 \mathrm{~h}$ and filled with the water (under vacuum). The vacuum was kept during $2 \mathrm{~h}$ after water addition in order to be sure that all the specimens were filled by the water. The total porosity was calculated using the apparent density and the theorical alumina density of $3.97 \mathrm{~g} \cdot \mathrm{cm}^{-3}$. Bulk density was characterised to be sure that the all the porosity was open or the closed porosity was very low.

The micropore volume fraction in the ceramic walls, or wall microporosity, was evaluated from the measurement of acoustic wave velocity in the specimens [26]. The measurement principle assumed that the ceramic walls act as a wave guide. Consequently, the velocity measured on the specimen is only function of the microporosity in the wall (Figure 2). It must be noted that the volume fraction, $p_{\mu}$, so determined, is relative to the ceramic walls and not to the whole specimen. To determine the microporosity faction $p_{M}$, relative to the whole specimen, one must take into account the total porosity $p$.

$$
p_{M}=\frac{(1-p)}{\left(1-p_{\mu}\right)} \cdot p_{\mu}
$$

The acoustic wave velocity was measured by mean of two transducers of nominal frequency $250 \mathrm{kHz}$ (Ultrasonic tester, Brutsaert, Belgium). The transducers were placed on opposite sides of the specimens with soft paraffin as coupling agent.

Determination of the micropores volume fraction, $p_{\mathfrak{u}}$, from the wave velocity required the use of a calibration curve (Figure 3). This curve was obtained using reference alumina specimens prepared by pressing and partial sintering at temperatures ranging from 1000 to $1600{ }^{\circ} \mathrm{C}$, covering a porosity range from 0 to $35 \%$. For each temperature, three specimens were tested and for each specimen, measurement was repeated six times.

The size of the macropores was measured using image analysis of scanning electron microscopy (SEM, JEOL JSM 5900 LV, Tokyo, Japan) micrographs. For each specimen, 15 micrographs and more than 150 pores were investigated (magnification: $\times 90$ ). The analysis was performed on a cross section at a depth of $2 \mathrm{~mm}$ from the specimen's upper surface (last frozen part). 


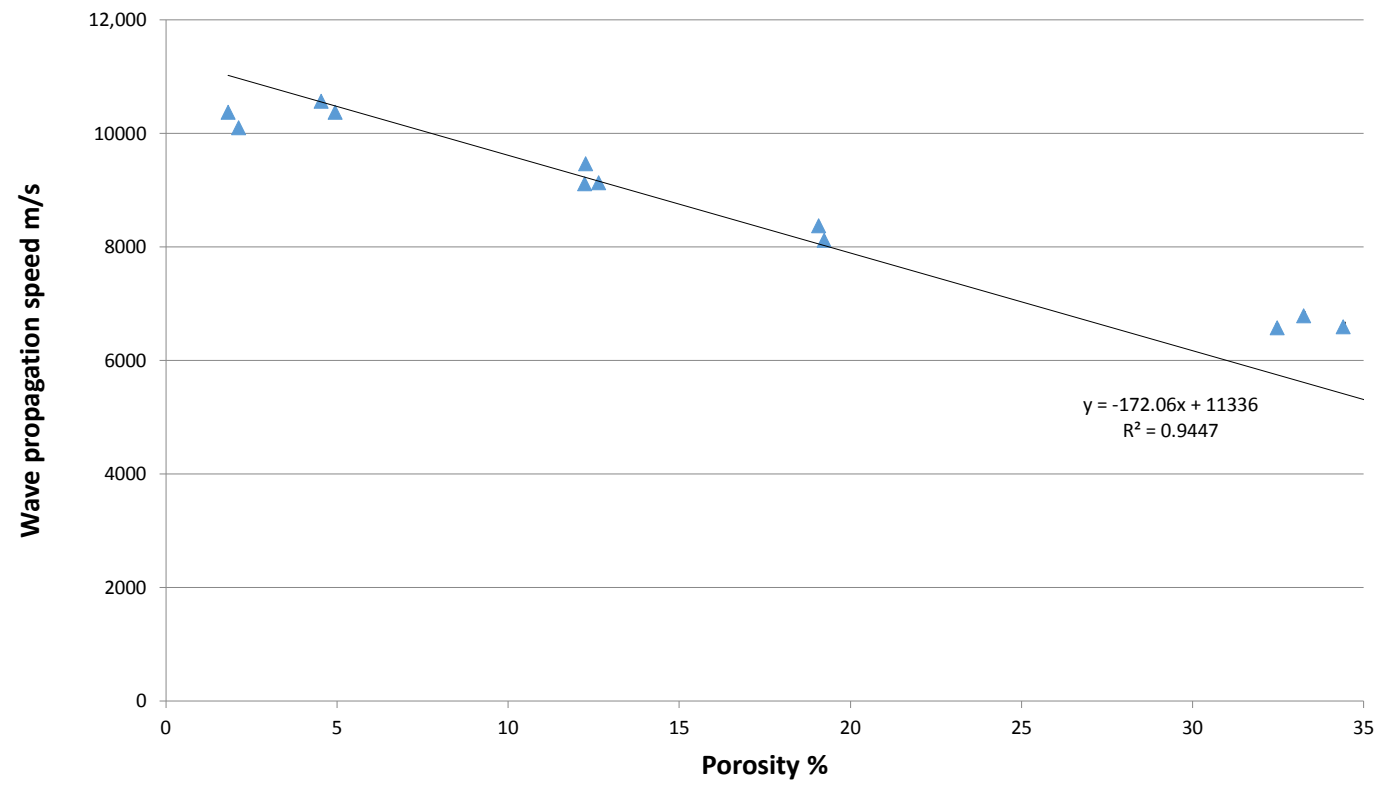

Figure 3. Standard curves of ultrasound wave propagation speed as a function of porosity for isotropic porous alumina.

Freezing may cause porosity gradients, along and transversally to the freezing axis. These gradients were characterized on a $4 \mathrm{~mm}$ thick axial slices of the specimens (Figure 3A) by X-ray radiography, HMX CT (X-TEK-NIKON, Tokyo, Japan). Three slices were analyzed for each freezing condition. The principle of the density measurement was based on the Beer-Lambert law (Equation (2)):

$$
I=I_{0} * e^{-\left(\frac{\mu}{\rho}\right) * \rho x}
$$

where $I_{0}$ is the radiant flux intensity received by the specimen, $I$ is the radiant flux intensity transmitted by the specimen, $\left(\frac{\mu}{\rho}\right)$ is the mass absorption coefficient, $\rho$ is the specimen density, and $x$ its thickness. On an X-ray image of a specimen, the intensity $I_{i}$ received at a point is transcribed by a grey level $N_{i}$, following Equation (3):

$$
I_{i}=N_{i}-N_{\infty}
$$

where $N_{\infty}$ is the grey level without X-ray (black). By substitution of intensity by grey level in Equation (3), we obtain:

$$
\left(N-N_{\infty}\right)=\left(N_{0}-N_{\infty}\right) e^{\left(-\left(\frac{\mu}{\rho}\right) * \rho x\right)}
$$

where $N$ and $N_{0}$ are the grey level with a specimen and without a specimen (white) respectively.

In the first step, the average grey level of the slice, $\bar{N}$, was measured. It corresponded to the average density, $\bar{\rho}$, of the whole slice. Both are linked by the equation (Equation (5)):

$$
\left(\bar{N}-N_{\infty}\right)=\left(N_{0}-N_{\infty}\right) e^{\left(-\left(\frac{\mu}{\rho}\right) * \bar{\rho} x\right)}
$$

In the second step, local grey level, $N_{l}$, was measured on an area of 0.5 by $0.5 \mathrm{~mm}$, every $1 \mathrm{~mm}$ along the $\mathrm{z}$ direction and at three different $\mathrm{y}$ positions (Figure 4B). Note that, as SEM images will further show, the volume analysed $\left(0.5 \times 0.5 \times 4 \mathrm{~mm}^{3}\right)$ was large enough to be considered as homogeneous with respect to the pore size. The grey level, $N_{l}$, was linked to the local density, $\rho_{l}$, by the equation (Equation (6)):

$$
\left(N_{l}-N_{\infty}\right)=\left(N_{0}-N_{\infty}\right) e^{\left(-\left(\frac{\mu}{\rho}\right) * \rho_{l} x\right)}
$$




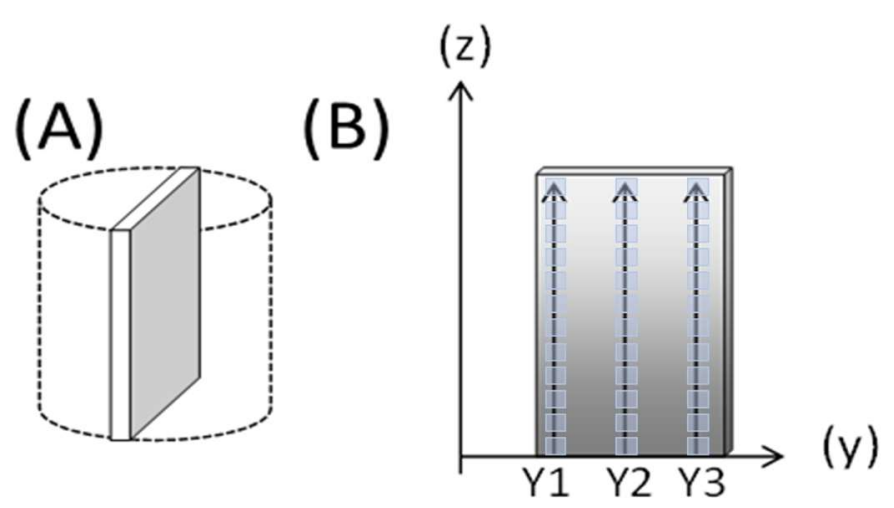

Figure 4. Schematic of local porosity level determination by X-ray radiography: (A) location of cut specimen and (B) location of measurement points.

From Equations (4) and (5), the local density is given by Equation (7):

$$
\frac{\ln \frac{\left(\bar{N}-N_{\infty}\right)}{\left(N_{l}-N_{\infty}\right)}}{\left(\frac{\mu}{\rho}\right) \cdot x}=\rho_{l}-\bar{\rho}
$$

Note that the mass absorption coefficient $\frac{\mu}{\rho}$ was considered as to be the same for Equations (5) and (6). Its value was determined from a calibration curve giving its evolution as a function of the mass thickness $\rho^{*} x$ (Figure 5).

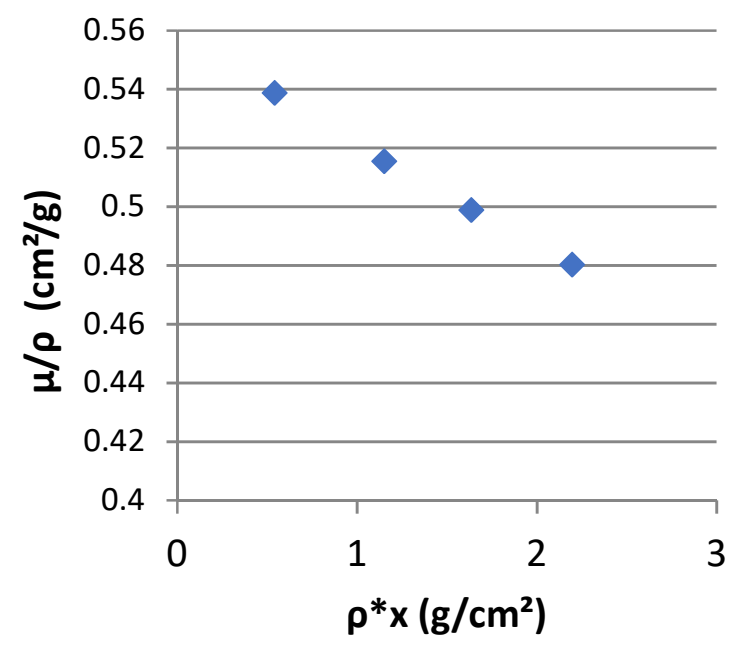

Figure 5. Mass absorption coefficient as a function of the mass thickness.

Uniaxial compression tests were used to analyse the deformation and fracture behaviour of the freeze cast porous ceramics. The surface of the specimens was softly grounded in order to obtain solid cylinders with parallel ends. The specimen dimensions were $25 \mathrm{~mm}$ diameter and $21 \mathrm{~mm}$ height. Compression tests were carried out parallel to the freezing direction of the specimens using an Instron test machine 1114 (Instron, Norwood, MA, USA), with a crosshead speed of $0.5 \mathrm{~mm} \cdot \mathrm{min}^{-1}$. Three specimens were tested for each material. The results are presented to show the average values and errors are the standard deviations. Engineering elastic modulus was determined using the slope of the curve after correction for the compliance of the machine and the loading supports. This last fact was determined using a dense alumina specimen of the same dimensions as the porous specimen. Macro- and microscopic analyses were carried out on the mechanical test specimens in order to 
determine the relation between structure and compressive behaviour. After the compressive tests, the complete specimens were embedded in resin under vacuum before cutting and polishing them for post mortem analyses by SEM analysis.

\section{Results}

\subsection{Microstructure}

Table 1 summarises the main material characteristics as a function of processing parameters. Figure 6 shows the typical structure of the freeze cast specimens. Cross sections parallel to the freezing direction (Figure 6A-D) illustrate two different structures depending on binder content. Without a binder, cracks perpendicular to the freezing direction were present (Figure 6A), as previously described by other authors [31]. This phenomenon was explained by the instability of the freezing front during the freezing process [32]. The addition of just a small quantity of binder leads to obtaining a structure without cracks (Figure 6B). In all cases, a lamellar morphology was kept. Results revealed that finer lamellae were obtained by increasing freezing rate, as indicated by other authors $[29,33,34]$.

Table 1. Porous structure characteristics versus process parameters. (the specimen name is powder content/binder content/freezing rate).

\begin{tabular}{|c|c|c|c|c|c|c|c|c|}
\hline \multirow{2}{*}{ Specimen } & \multirow{2}{*}{$\begin{array}{c}\text { Alumina } \\
\text { Content (vol. \%) }\end{array}$} & \multirow{2}{*}{$\begin{array}{l}\text { Binder Content } \\
\text { (wt. \%) }\end{array}$} & \multirow{2}{*}{$\begin{array}{l}\text { Freezing Rate } \\
\left(\mathrm{K} \cdot \mathrm{min}^{-1}\right)\end{array}$} & \multicolumn{2}{|c|}{ Pore Size $(\mu \mathrm{m})$} & \multirow{2}{*}{$\begin{array}{c}\text { Lamellar } \\
\text { Thickness }(\mu \mathrm{m})\end{array}$} & \multirow{2}{*}{$\begin{array}{c}\text { Bulk Density } \\
\left(\mathrm{g} \cdot \mathrm{cm}^{-3}\right)\end{array}$} & \multirow{2}{*}{$\begin{array}{c}\text { Total } \\
\text { Porosity (\%) }\end{array}$} \\
\hline & & & & Minor Axis & Major Axis & & & \\
\hline $28 / 0 / 1$ & 28 & 0 & 1 & $40 \pm 12$ & $300 \pm 130$ & $35 \pm 11$ & $3.94 \pm 0.01$ & $57 \pm 1$ \\
\hline $28 / 3 / 1$ & 28 & 3 & 1 & $40 \pm 7$ & $300 \pm 100$ & $41 \pm 15$ & $3.95 \pm 0.01$ & $55 \pm 1$ \\
\hline $28 / 3 / 5$ & 28 & 3 & 5 & $28 \pm 7$ & $190 \pm 100$ & $30 \pm 8$ & $3.97 \pm 0.01$ & $56 \pm 1$ \\
\hline $28 / 3 / 20$ & 28 & 3 & 20 & $6 \pm 2$ & $13 \pm 5$ & $3 \pm 1$ & $3.97 \pm 0.01$ & $54 \pm 1$ \\
\hline $28 / 6 / 1$ & 28 & 6 & 1 & $42 \pm 15$ & $150 \pm 100$ & $35 \pm 15$ & $3.96 \pm 0.01$ & $44 \pm 1$ \\
\hline $33 / 0 / 20$ & 33 & 0 & 20 & $13 \pm 3$ & $100 \pm 70$ & $20 \pm 71$ & $3.97 \pm 0.01$ & $44 \pm 1$ \\
\hline $33 / 3 / 1$ & 33 & 3 & 1 & $40 \pm 12$ & $250 \pm 100$ & $36 \pm 11$ & $3.97 \pm 0.01$ & $40 \pm 1$ \\
\hline $33 / 6 / 1$ & 33 & 6 & 1 & $34 \pm 9$ & $200 \pm 200$ & $33 \pm 12$ & $3.96 \pm 0.01$ & $44 \pm 1$ \\
\hline
\end{tabular}
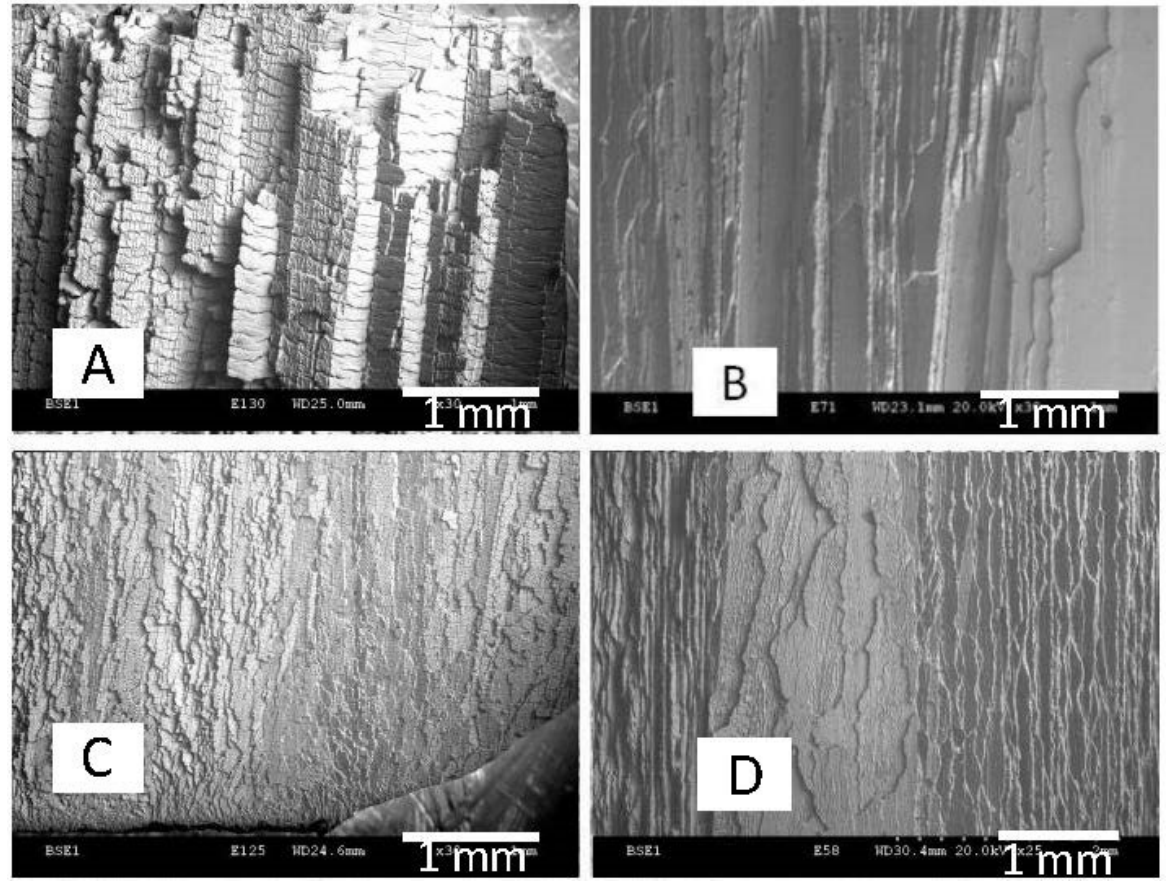

Figure 6. Cont. 


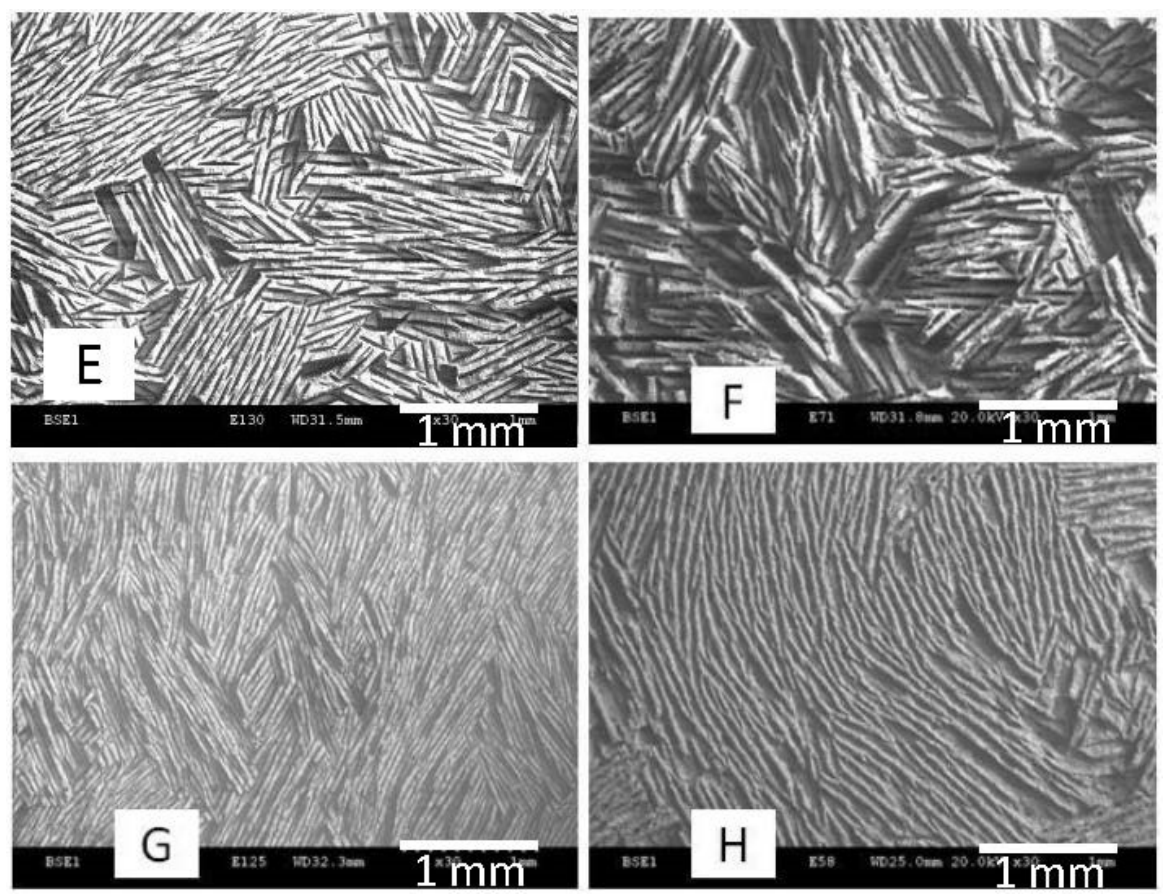

Figure 6. SEM micrographs of cross section parallel (A-D) and perpendicular (E-H) to the freezing direction of freeze cast anisotropic porous specimens as a function of processing parameter (28 wt. \% alumina). (A,C,E,G) without binder; $(\mathbf{B}, \mathbf{F})$ with 3 wt. \% of binder; $(\mathbf{D}, \mathbf{H})$ with 6 wt. \% of binder. $(\mathrm{C}, \mathrm{G})$ frozen at $20 \mathrm{~K} / \mathrm{min}$, others at $1 \mathrm{~K} / \mathrm{min}$.

Cross sections perpendicular to the freezing direction (Figure $6 \mathrm{E}-\mathrm{H}$ ) show the typical elliptical pore morphology [35] characterised by minor and major axes. For both, freezing rate had a strong impact; changes in the minor and major axis from 40 to $6 \mu \mathrm{m}$ and from 300 to $13 \mu \mathrm{m}$, respectively, were found for the freezing rates employed (Table 1). Other parameters (powder and binder contents) had a limited impact on the minor axis but its increase led to a reduction of the major axis, as discussed by different authors $[34,36]$.

The parameter having the largest impact on the total porosity level was the powder content [10] (Table 1), as observed by several authors in different systems: alumina [9], zirconia [37], hydroxyapatite [22], etc. Porosity level decreased from 57 to $40 \%$ when the powder content increased from 28 to 33 vol. \%. This variation can be explained because the porosity was the replica of the frozen water during the process of sublimation and the increase of powder content resulted in a decrease in the water content [38].

\subsection{Mechanical Characterisation}

Figure 7 shows stress-strain behaviour of the freeze cast specimens tested in compression with the load parallel to the freezing direction. The specimens processed without binder presented very low mechanical properties and a different behaviour regarding the other specimens where the same tendancies were observed. Indeed, a similar behaviour was also observed previously by $\mathrm{H}$. Lu et al. [16]. Three domains can be observed in the curve: an initial linear region up to a failure, followed by a sharp decrease and subsequent increase up to a failure region in which significant strain occurred. However, more specific behaviours were identified as the function of processing parameters. When the powder content was higher, at 33 vol. \%, the failure region was short and the increase was not significant, indeed a short plateau region was observed after the failure, which might correspond to the decreased porosity effect. In the case of specimen processed with $6 \mathrm{wt}$. \% binder, the behaviour changed after the failure where an important increase of the stress was observed and located in the 
failure region. This important modification led to the assumption that an important modification of the microstructure when high binder content was used. In the literature, some authors have linked the increase of binder content and the formation of "bridges" [36,39], which might improve the mechanical strength and explain the modification of the behaviour.

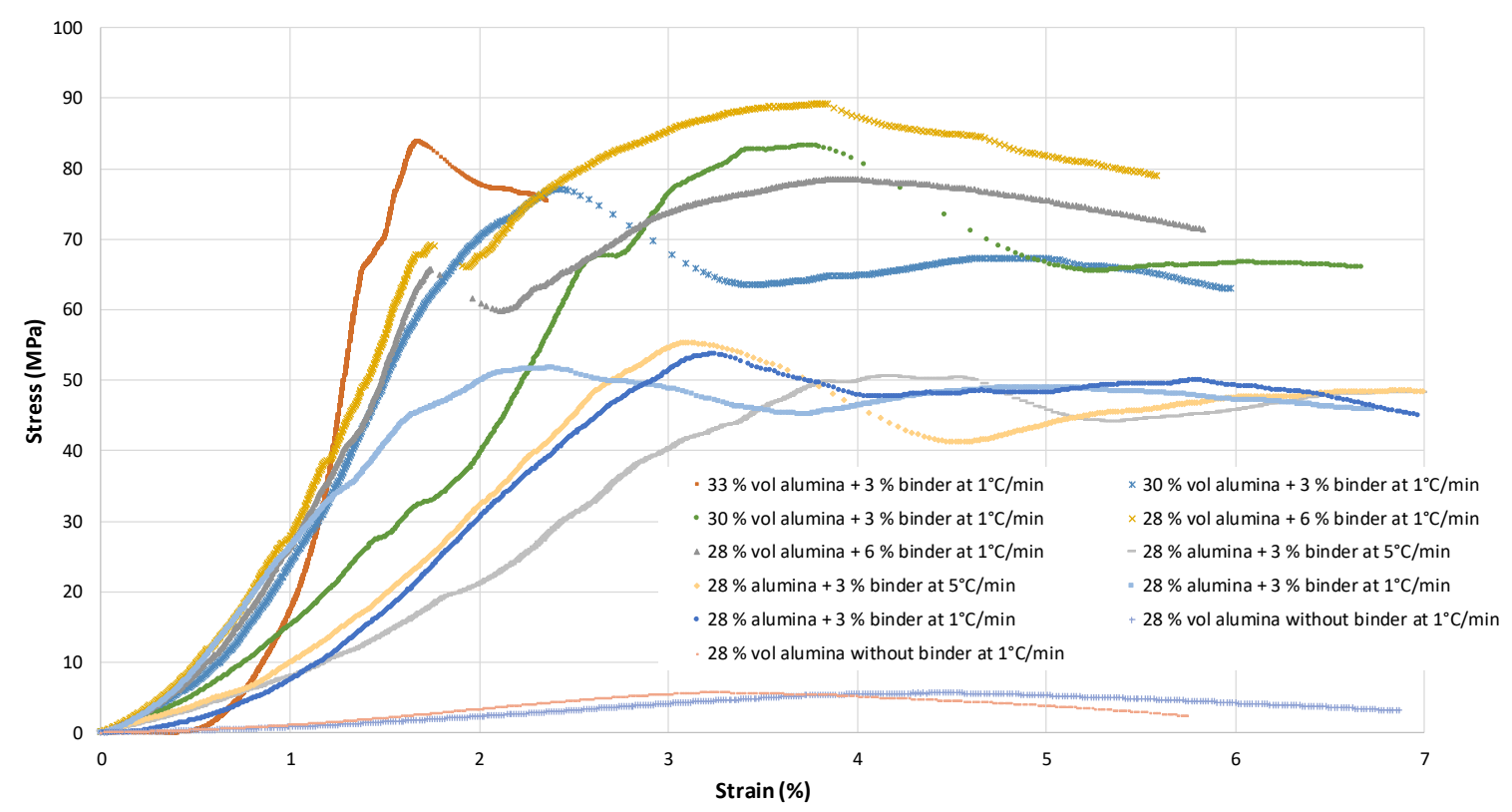

Figure 7. Stress measurement of anisotropic porous alumina specimen processed at different parameters.

Figure 8 shows the macroscopic aspect after testing of processed specimens. Only the region of the specimen corresponding to the last frozen volume was damaged during the test. A trapezoidal macroscopic deformation was obtained and it shows that the specimens deform differently along their height.

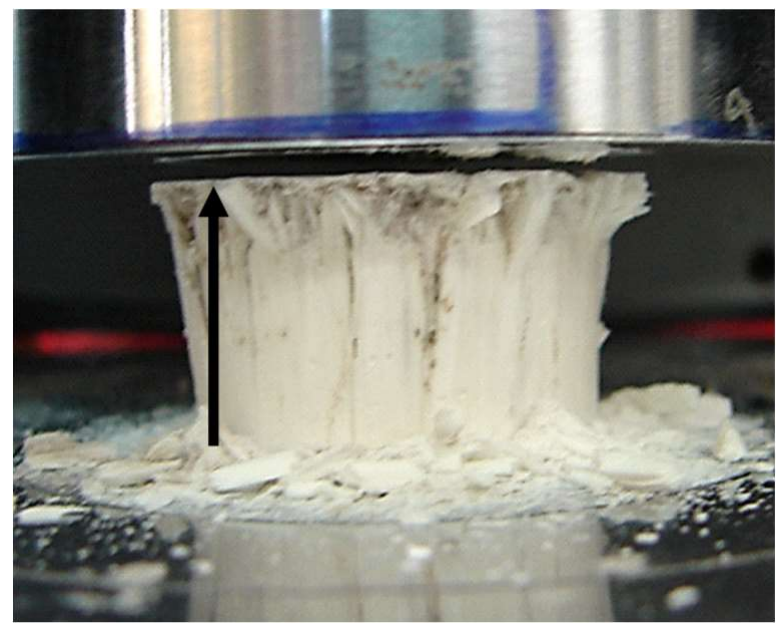

Figure 8. Image of porous alumina specimen during compressive test. The dark arrows represent the freezing direction during the freeze casting.

Figure 9 shows the typical structure of a freeze cast specimen after the compression test. The cross section parallel to the freezing direction shows the lamellae deformation and rupture. As revealed in Figure 8, for the macroscopic deformation, only the top part of the specimens, corresponding to 
the last frozen region, were modified by the compression test and was totally damaged (Figure 9A,B) after testing.

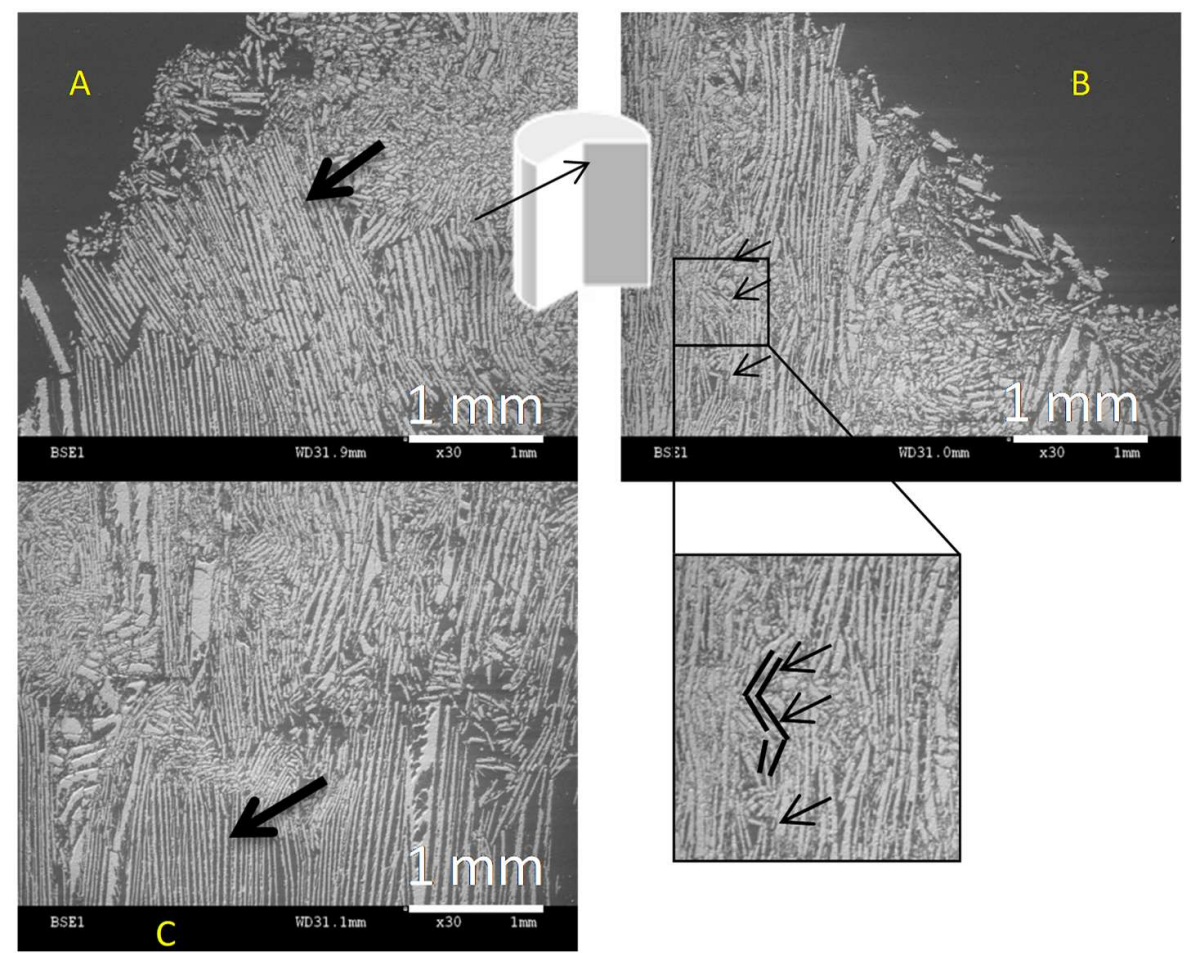

Figure 9. SEM micrographs of a specimen processed at $1 \mathrm{~K} / \mathrm{min}$, from a slurry with $28 \mathrm{vol}$. $\%$ of alumina and $3 \mathrm{wt}$ \% of binder. (A) top left; (B) top right and (C) centre of the specimen.

The lamellae presented two different modifications: displacement and fracture, as highlighted by the black arrows in Figure 8. The displacement of the lamellae (Figure 9A) was perpendicular to the load direction during the test. Deformation of the lamellae before fracture (Figure 9B) was similar to that of specimens characterised by 3-point bending tests, with a " $\mathrm{S}$ " shape.

Values of the compressive strength and apparent elastic modulus are summarized in Table 2. They ranged from 6 to $111 \mathrm{MPa}$ for the compressive strength and from 0.2 to $14 \mathrm{GPa}$ for the apparent elastic modulus depending, in particular, on two significant process parameters: binder content and freezing rate. Indeed, the addition of $3 \mathrm{wt}$. \% of binder led to a compressive strength value 9 times higher than binder-free specimens and an elastic modulus value 15 times higher than binder free specimens, due to the elimination of cracks. The highest compressive strength was obtained at the highest freezing rate, which means that the pore size had a major impact on the compressive strength, because the total porosity level was not modified. It was also observed that mechanical characteristics were improved by increasing powder content in slurry, which resulted in a decrease of the total porosity level.

Table 2. Mechanical properties of anisotropic porous alumina as a function of processing parameters.

\begin{tabular}{ccc}
\hline Specimen & Apparent Compressive Strength (MPa) & Apparent Elastic Modulus (GPa) \\
\hline $28 / 0 / 1$ & $6 \pm 1$ & $0.2 \pm 0.1$ \\
$28 / 3 / 1$ & $56 \pm 9$ & $3 \pm 1$ \\
$28 / 3 / 5$ & $55 \pm 3$ & $2 \pm 1$ \\
$28 / 3 / 20$ & $111 \pm 9$ & $6 \pm 1$ \\
$28 / 6 / 1$ & $88 \pm 8$ & $7 \pm 2$ \\
$33 / 3 / 1$ & $80 \pm 5$ & $14 \pm 1$ \\
\hline
\end{tabular}


Figure 10 presents the porosity gradient of a specimen processed at a freezing rate of $1{ }^{\circ} \mathrm{C} / \mathrm{min}$ with a slurry content of $28 \mathrm{vol}$. \% alumina and $3 \mathrm{wt}$. \% binder, as a function of specimen height. The porosity seemed to be similar perpendicular to the freezing direction (along $y$ axis). However, a variation of the porosity level through the specimen height ( $z$ axis) was clearly observed. This can be divided in three zones. Porosity level was relatively low at the bottom part of the specimen, with an initial value of about $30 \%$ (zone 1). The overall specimen, between 5 and $19 \mathrm{~mm}$, exhibited a slight change of the porosity level from around 50 to $53 \%$ (zone 2). At the top part, the porosity level was higher, reaching a value of about $70 \%$ (zone 3 ).

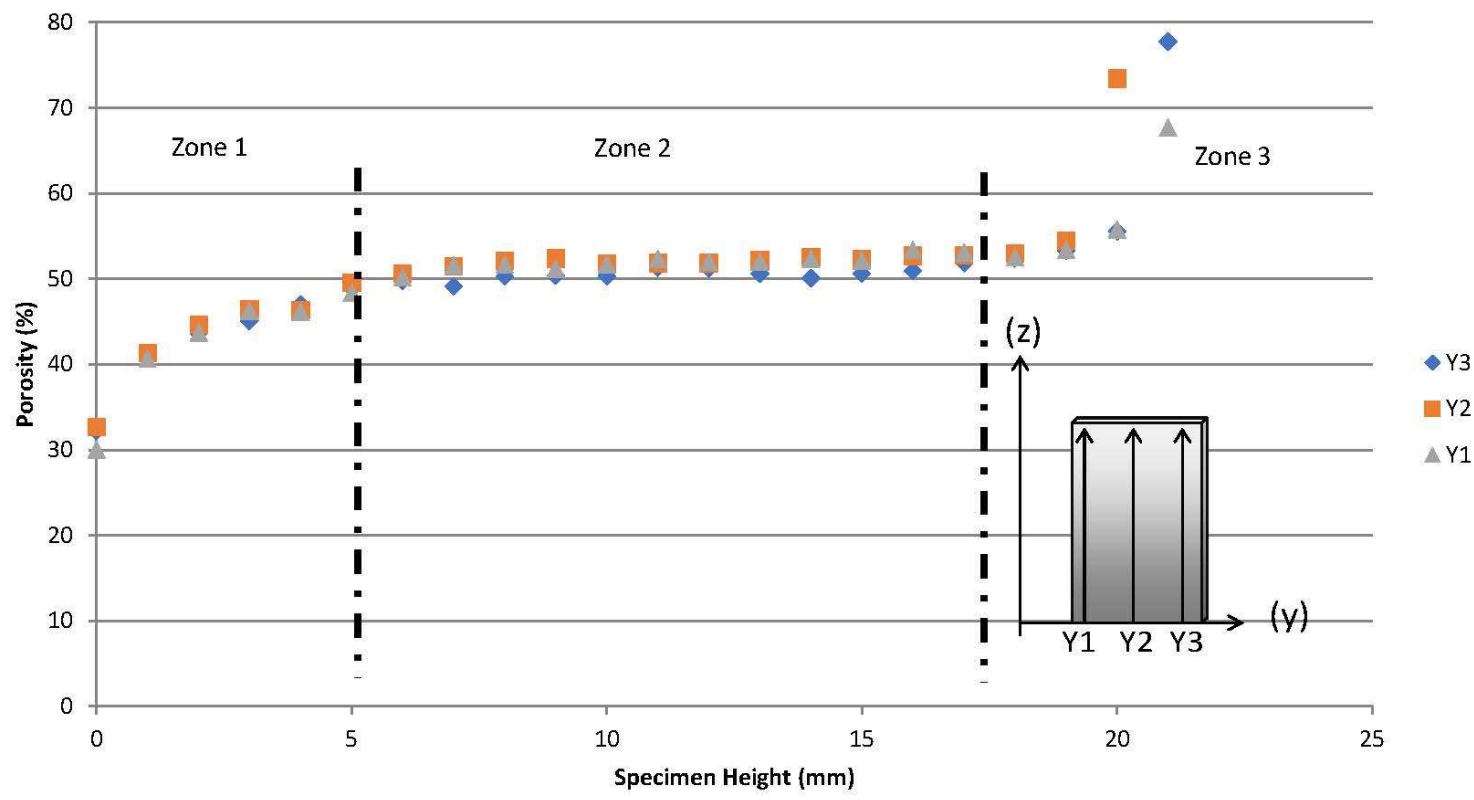

Figure 10. Porosity gradient measurement along $\mathrm{z}$ axis of a specimen: slurry containing $28 \mathrm{vol}$. $\%$ alumina $+3 \mathrm{wt}$. \% binder and frozen at $1 \mathrm{~K} / \mathrm{min}$.

\section{Discussion}

\subsection{Deformation Behaviour}

The compression behaviour can be described in four steps as shown in Figure 11. During the first stage, no macroscopic damage was observed, the lamellae would shrink in the direction of loading (Figure 11A). When the applied load increased, the lamellae experienced flexure (Figure 11B) until their fracture (Figure 11C). This is related to the lamellae shape observed by SEM after the compression test. Indeed, the lamellae of the top part were broken during the test with an "S" shape as shown in Figure 9B. Finally, lamellae fragments could fill the adjacent porosity which allowed the structure to be pushed towards the adjacent surfaces (Figure 11D).

This behaviour can be explained by a porosity gradient from top to bottom through the structure, with a denser part at the bottom and more porous at the top. In order to verify this assumption, the porosity level was assessed through the specimens using X-ray radiography.

Figure 12 presents the average of all measurements (Y1, Y2 and $\mathrm{Y} 3$ ) for specimens obtained under different processing parameters. All the specimens exhibited the same behaviour as explained previously for the specimen processed from an alumina slurry with a powder content of $28 \mathrm{vol} . \%$ and a binder content of $3 \mathrm{wt}$. $\%$ at a freezing rate of $1{ }^{\circ} \mathrm{C} / \mathrm{min}$. The porosity gradient can be explained by the study performed by Deville et al. [40] during the first stage of freezing. Indeed, the denser part of the specimen may correspond to the cellular morphology (isotropic porous part) produced at the first stage of freezing with a fast and stable freezing front. Zone 2 (only a small variation in porosity level) corresponded to the metastable region where the anisotropic structure was obtained. 

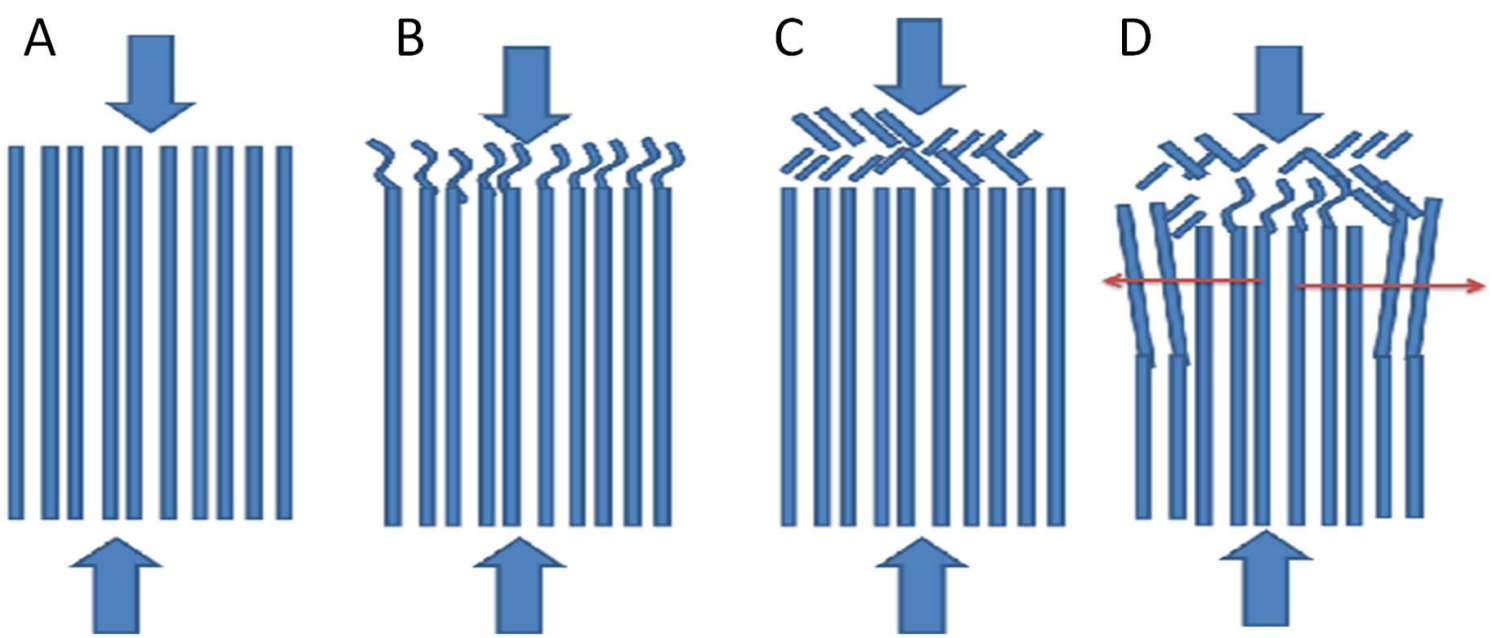

Figure 11. Schematic of rupture mode of a freeze cast specimen during the compression test. (A) at start of load application; (B) lamellae deformation when the load increases; (C) lamellae fracture. By further increase of the load, lamellae pieces filled the pore and push the other lamellae to obtain a trapezoidal shape (D).

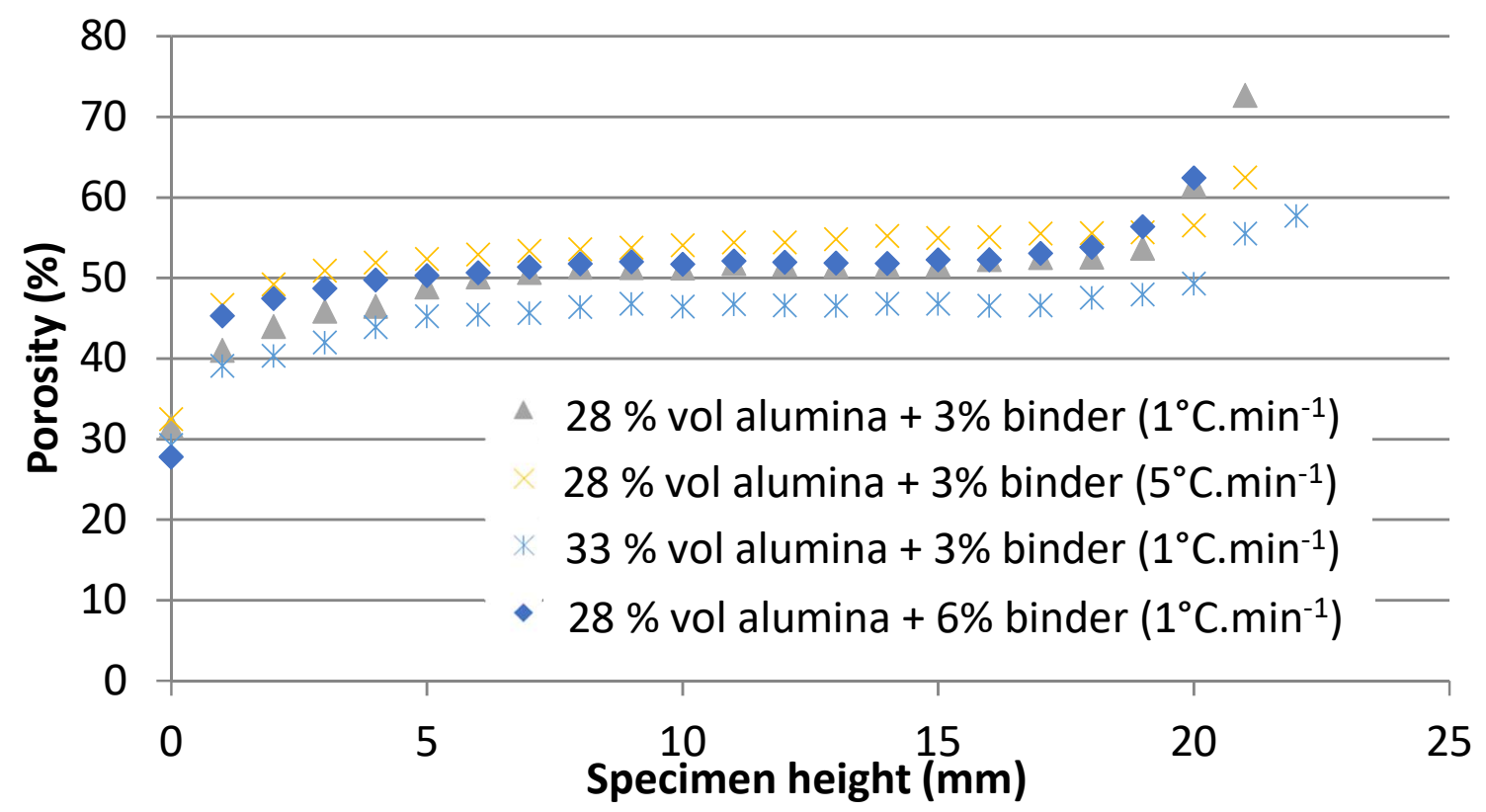

Figure 12. Porosity gradient measurement of specimens processed under different conditions. Each measurement point is an average value of $\mathrm{Y} 1, \mathrm{Y} 2$ and $\mathrm{Y} 3$.

At the top part, because of the previous step (larger consumption of powder), there was a depletion of the powder content, which led to the formation of a more porous part. These analyses confirmed this assumption and explained the deformation behaviour of the specimen: the top part of the specimen was more porous and the local mechanical properties were lower, which induced the trapezoidal deformation observed during the final stage of the mechanical tests.

\subsection{Deformation Behaviour}

The relation between the structure of a porous material and its associate mechanical properties is not easy to determine, particularly in the case of anisotropic porous ceramics processed by freeze casting. A simple exponential model is usually used to describe the relation between compressive 
strength and porosity level [21] but does not allow an explanation for all the observations. Indeed, in the case of a specimen processed without binder, even if the porosity level is slightly higher (by about $2 \%$ ), the use of this kind of model is not recommended because of the cracks (perpendicular to the freezing direction), which dramatically decrease the compressive strength. Another analytical model taking into account the porosity of the lamellae, called "micro porosity", was proposed [27], using Equation (8) to calculate the compressive strength.

$$
\sigma=\sigma_{0} C_{1}\left(\frac{(1-p)^{\frac{3}{2}}}{\left(1-p_{M}\right)^{\frac{1}{2}}}\right)\left(1+\left(\frac{1-p}{1-p_{M}}\right)^{\frac{1}{2}}\right)
$$

where $p$ and $p_{M}$ are the total and the micro porosity, respectively, $C_{1}$ is a constant determined experimentally with a value of $0.23, \sigma$ and $\sigma_{0}$ are the compressive strength of the porous specimen, and the dense material of $3 \mathrm{GPa}$, respectively.

The wall microporosity was determined using an acoustic technique on specimens with binder, because the presence of cracks does not allow the use of the acoustic technique for determining the microporosity for specimens processed without binder. Results are summarized in Table 3 for specimens processed from alumina slurries containing from 28 to $33 \mathrm{vol}$. \% of powder and with a constant binder content of $3 \mathrm{wt}$. \% and the same freezing rate of $1{ }^{\circ} \mathrm{C} / \mathrm{min}$ to avoid pore size and bridge size effect issues. This way, only the macro and micro porosity were taken into account.

Table 3. Wall microporosity and microporosity of anisotropic porous alumina as a function of powder content.

\begin{tabular}{ccc}
\hline Specimen & Wall Porosity $\mathbf{P}_{\boldsymbol{\mu}} \mathbf{( \% )}$ & Microporosity $\mathbf{P}_{\mathbf{M}} \mathbf{( \% )}$ \\
\hline $28 / 3 / 1$ & $14 \pm 1$ & $\sim 6$ \\
$30 / 3 / 1$ & $13 \pm 1$ & $\sim 6$ \\
$33 / 3 / 1$ & $7.7 \pm 0.4$ & $\sim 5$ \\
\hline
\end{tabular}

The analytical model (Equation (8)) was applied. However, the calculated compressive strengths were unexpectedly very high, from 600 to $800 \mathrm{MPa}$, ten times more than experimental values. Considering the strain behaviour observed and the assumption made previously about the " $\mathrm{S}$ " shaped deformation of the lamellae, Equation (8) can be modified by the replacement of the compressive strength of a dense material by the flexural strength. By this way, Equation (9) is obtained:

$$
\sigma=\sigma_{f 0} C_{1}\left(\frac{(1-p)^{\frac{3}{2}}}{\left(1-p_{M}\right)^{\frac{1}{2}}}\right)\left(1+\left(\frac{1-p}{1-p_{M}}\right)^{\frac{1}{2}}\right)
$$

where $\sigma_{f 0}$ is the flexural strength of the dense material of $300 \mathrm{MPa}$. The analytical model was applied and the results are plotted in Figure 13. In that case, the calculated and experimental values fit much better than with the compressive strength of dense alumina. The above discussion shows that the cylindrical porous specimens processed by freeze casting studied in this work did not present the characteristic stress-strain behaviour under compression shown by porous materials. When these specimens were loaded parallel to the freezing direction, the lamellae bent in the direction perpendicular to the load and the strength of the specimen was determined when the fracture occurs. 


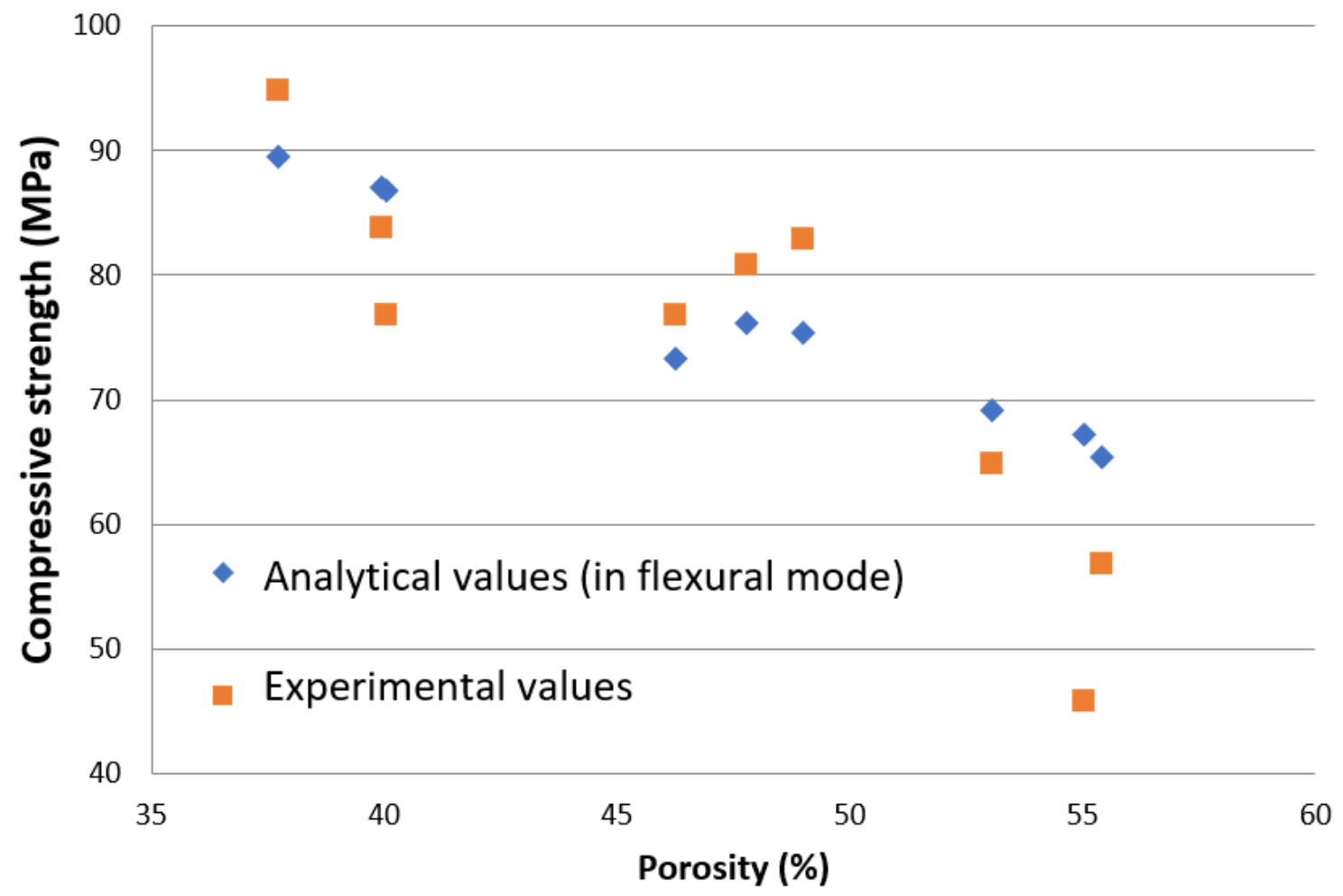

Figure 13. Compressive strength of porous anisotropic alumina as a function of the porosity level. Comparison of experimental and analytical values for the specimens characterised in Table 3.

\section{Conclusions}

Freeze casting by ice templating was used to process porous alumina exhibiting a unidirectional porous structure. The specimens had an overall porosity level from 40 to $57 \%$, depending on powder content. The pore size ranged from $6 \mu \mathrm{m}$ to $42 \mu \mathrm{m}$ for the minor and $13 \mu \mathrm{m}$ to $300 \mu \mathrm{m}$ for the major axis, which depended on freezing rate and powder and binder contents. The freeze cast specimen presented a compressive strength ranging from $6 \mathrm{MPa}$ to $111 \mathrm{MPa}$ and an apparent elastic modulus ranging from $0.2 \mathrm{GPa}$ to $14 \mathrm{GPa}$, depending on processing parameters.

The mechanical study of freeze cast anisotropic ceramic showed that such a structure exhibits a non-classic strain. A macroscopic trapezoidal strain of the specimen was observed during the compressive test depending on two phenomena:

- A porosity gradient through the height of the specimen of about $40 \%$ between the bottom and top part of the specimen, which was determined by X-ray radiography.

- The flexural rupture mode of the lamellae during the compressive test.

An analytical model based on a Gibson and Ashby relation was used to predict the compressive strength of anisotropic porous alumina. Considering the flexural rupture mode of the lamellae, the analytical model was adapted using the theoretical flexural strength value instead of the compressive strength of dense alumina. While only the change of the porosity level was taken into account, it was observed that the structure can be modified in terms of pore size, bridges, etc. Therefore, the analytical model used in this work should allow such structural modification to be taken into account.

Author Contributions: Experiments were conducted by D.H., and conceived by D.H., M.G. and C.B. The results and their implications were discussed by D.H., C.B., M.G., F.C., V.L. and A.L. All authors reviewed the manuscript.

Funding: This research received no external funding. 
Acknowledgments: FSE: DGO6 and BCRC are acknowledged for their financial support to Dominique Hautcoeur $\mathrm{PhD}$ thesis (grant number ECV320600FDOO7F/1017208/ECOPOR, subvention FIRST DOCTORAT Centre Agréé International).

Conflicts of Interest: The authors declare no conflict of interest. The founding sponsors had no role in the design of the study; in the collection, analyses, or interpretation of data; in the writing of the manuscript, and in the decision to publish the results.

\section{References}

1. Xing, Z.; Li, J.; Wang, Q.; Zhou, W.; Tian, G.; Pan, K.; Tian, C.; Zou, J.; Fu, H. A Floating Porous Crystalline $\mathrm{TiO}_{2}$ Ceramic with Enhanced Photocatalytic Performance for Wastewater Decontamination. Eur. J. Inorg. Chem. 2013, 13, 2411-2417. [CrossRef]

2. Meurice, E.; Bouchart, F.; Hornez, J.C.; Leriche, A.; Hautcoeur, D.; Lardot, V.; Cambier, F.; Fernandes, M.H.; Monteiro, F. Osteoblastic cells colonization inside beta-TCP macroporous structures obtained by ice-templating. J. Eur. Ceram. Soc. 2016, 36, 2895-2901. [CrossRef]

3. Guo, R.; Wang, C.A.; Yang, A. Effects of pore size and orientation on dielectric and piezoelectric properties of 1-3 type porous PZT ceramics. J. Eur. Ceram. Soc. 2011, 31, 605-609. [CrossRef]

4. Kouras, N.; Harabi, A.; Bouzerara, F.; Foughal, L.; Policicchio, A.; Stelitano, S.; Galiano, F.; Figoli, A. Macro-porous ceramic support for membranes prepared from quartz sand and calcite mixtures. J. Eur. Ceram. Soc. 2017, 37, 3159-3165. [CrossRef]

5. Nait-ali, B.; Haberko, K.; Vesteghem, H.; Absi, J.; Smith, D.S. Thermal conductivity of highly porous zirconia. J. Eur. Ceram. Soc. 2006, 26, 3567-3574. [CrossRef]

6. Chen, Y.; Bunch, J.; Li, T.; Mao, Z.; Chen, F. Novel functionally graded acicular electrode for solid oxide cells fabricated by the freeze-tape-casting process. J. Power Sources 2012, 213, 93-99. [CrossRef]

7. Ziegler, T.; Neubrand, A.; Piat, R. Multiscale homogenization models for the elastic behaviour of metal/ceramic composites with lamellar domains. Compos. Sci. Technol. 2010, 70, 664-670. [CrossRef]

8. Colombo, P. Ceramic Foams: Fabrication, Properties, and Applications. Key Eng. Mater. 2002, 206-213, $1913-1918$. [CrossRef]

9. Nakazawa, H.; Yamada, H.; Fujita, T.; Ito, Y. Texture control of clay-aerogel through the crystallization process of ice. Clay Sci. 1987, 6, 269-276.

10. Deville, S. Freeze casting of porous ceramics: A review of current achievements and issues. Adv. Eng. Mater. 2008, 10, 155-169. [CrossRef]

11. Waschkies, T.; Oberacker, R.; Hoffmann, M.J. Control of Lamellae Spacing During Freeze Casting of Ceramics Using Double-Side Cooling as a Novel Processing Route. J. Am. Ceram. Soc. 2006, 92, S79-S84. [CrossRef]

12. De Marcos, A.; Nait-Ali, B.; Tessier-Doyen, N.; Alzina, A.; Pagnoux, C.; Peyratout, C.S. Influence of the ice front velocity and of the composition of suspensions on thermal properties of bentonite materials prepared using freeze-casting process. J. Eur. Ceram. Soc. 2014, 34, 4433-4441. [CrossRef]

13. Sellinger, A.; Weiss, P.M.; Nguyen, A.; Lu, Y.; Assink, R.A.; Gong, W.; Brinker, C.J. Continuous self-assembly of organic-inorganic nanocomposite coatings that mimic nacre. Nature 1998, 394, 256-260. [CrossRef]

14. Munch, E.; Franco, J.; Deville, S.; Hunger, P.; Saiz, E.; Tomsia, A.P. Porous Ceramic Scaffolds with Complex Architectures. JOM 2008, 60, 54-58. [CrossRef]

15. Hunger, P.M.; Donius, A.E.; Wegst, U.G.K. Platelets Self-assemble into Porous Nacre during Freeze Casting. J. Mech. Behav. Biomed. 2013, 19, 87-93. [CrossRef] [PubMed]

16. Hu, L.; Zhang, Y.; Dong, S.; Zhang, S.; Li, B. In situ growth of hydroxyapatite on lamellar alumina scaffolds with aligned pore channels. Ceram. Int. 2013, 39, 6287-6291. [CrossRef]

17. Hunger, P.M.; Donius, A.E.; Wegst, U.G.K. Structure-property-processing correlations in freeze-cast composite scaffolds. Acta Biomater. 2013, 9, 6338-6348. [CrossRef] [PubMed]

18. Zuo, K.H.; Zeng, Y.-P.; Jiang, D. Properties of Microstructure-Controllable Porous Yttria-Stabilized Ziroconia Ceramics Fabricated by Freeze Casting. Int. J. Appl. Ceram. Technol. 2008, 5, 198-203. [CrossRef]

19. Li, Z.; Zhang, Y.; Zhang, D.; Zhang, X.; Zhou, K. Porous hydroxyapatite ceramics fabricated by an ice-templating method. Scr. Mater. 2011, 64, 426-429.

20. Zhao, K.; Tang, Y.-F.; Qin, Y.-S.; Wei, J.-Q. Porous hydroxyapatite ceramics by ice templating: Freezing characteristics and mechanical properties. Ceram. Int. 2011, 37, 635-639. [CrossRef] 
21. Hong, C.; Zhang, X.; Han, J.; Du, J.; Zhang, W. Camphene-based freeze-cast $\mathrm{ZrO}_{2}$ foam with high compressive strength. Mater. Chem. Phys. 2010, 119, 359-362. [CrossRef]

22. Fu, Q.; Rahaman, M.N.; Dogan, F.; Bal, B.S. Freeze Casting of Porous Hydroxyapatite Scaffolds. I. Processing and General Microstructure. J. Biomed. Mater. Res. B 2007, 86, 125-135. [CrossRef] [PubMed]

23. Fu, Q.; Rahaman, M.N.; Dogan, F.; Bal, B.S. Freeze Casting of Porous Hydroxyapatite Scaffolds. II. Sintering, Microstructure, and Mechanical Behavior. J. Biomed. Mater. Res. B 2007, 86, 514-522. [CrossRef] [PubMed]

24. Seuba, J.; Deville, S.; Guizard, C.; Stevenson, A.J. Mechanical properties and failure behavior of unidirectional porous ceramics. Sci. Rep. 2016, 6, 24326. [CrossRef] [PubMed]

25. Zhang, J.; Ashby, M.F. The Out-of-Plane Properties of Honeycombs. Int. J. Mech. Sci. 1992, 34, 475-489. [CrossRef]

26. Hautcoeur, D.; Lorgouilloux, Y.; Leriche, A.; Gonon, M.; Nait-Ali, B.; Smith, D.S.; Lardot, V.; Cambier, F. Thermal conductivity of ceramic/metal composites from preforms produced by freeze casting. Ceram. Int. 2016, 42, 14077-14085. [CrossRef]

27. Li, J.-C.; Dunand, D.-C. Mechanical properties of directionally freeze-cast titanium foams. Acta Mater. 2011, 59, 146-158. [CrossRef]

28. Shanti, N.O.; Araki, K.; Halloran, J.W. Particle Redistribution during Dendritic Solidification of Particle Suspensions. J. Am. Ceram. Soc. 2006, 89, 2444-2447. [CrossRef]

29. Fukasawa, T.; Ando, M. Synthesis of Porous Ceramics with Complex Pore Structure by Freeze-Dry Processing. J. Am. Ceram. Soc. 2001, 84, 230-232. [CrossRef]

30. Fukushima, M.; Nakata, M.; Yoshizawa, Y. Fabrication and properties of ultra-highly porous cordierite with oriented micrometer-sized cylindrical pores by gelation and freezing method. J. Ceram. Soc. Jpn. 2008, 116, 1322-1325. [CrossRef]

31. Deville, S.; Maire, E.; Lasalle, A.; Bogner, A.; Gauthier, C.; Leloup, J.; Guizard, C. Metastable and unstable cellular solidification of colloidal suspensions. Nat. Mater. 2009, 8, 966-974. [CrossRef] [PubMed]

32. Lasalle, A.; Guizard, C.; Maire, E.; Adrien, J.; Deville, S. Particle redistribution and structural defect development during ice templating. Acta Mater. 2012, 60, 4594-4603. [CrossRef]

33. Deville, S.; Saiz, E.; Tomsia, A.P. Freeze casting of hydroxyapatite scaffolds for bone tissue engineering. Biomaterials 2006, 27, 5480-5489. [CrossRef] [PubMed]

34. Pekor, C.M.; Kisa, P.; Nettleship, I. Effect of Polyethylene Glycol on the Microstructure of Freeze-Cast Alumina. J. Am. Ceram. Soc. 2008, 91, 3185-3190. [CrossRef]

35. Ananth, R.; Gill, W.N. Dendritic growth of an elliptical paraboloid with forced convection in the melt. J. Fluid Mech. 1989, 208, 575-593. [CrossRef]

36. Zuo, K.H.; Zeng, Y.-P.; Jiang, D. Effect of polyvinyl alcohol additive on the pore structure and morphology of the freeze-cast hydroxyapatite ceramics. Mater. Sci. Eng. C 2010, 30, 283-287. [CrossRef]

37. Sofie, S.W. Fabrication of Functionally Graded and Aligned Porosity in Thin Ceramic Substrates with the Novel Freeze-Tape-Casting Process. J. Am. Ceram. Soc. 2007, 90, 2024-2031. [CrossRef]

38. Liu, G.; Zhang, D.; Meggs, C.; Button, T.W. Porous $\mathrm{Al}_{2} \mathrm{O}_{3}-\mathrm{ZrO}_{2}$ composites fabricated by an ice template method. Scripta Mater. 2010, 62, 466-468. [CrossRef]

39. Gang, L. Fabrication of Porous Ceramics and Composites by a Novel Freeze Casting Process. Ph.D. Thesis, University of Birmingham, Birmingham, UK, March 2011.

40. Deville, S.; Maire, E.; Lasalle, A.; Bogner, A.; Gauthier, C.; Leloup, J.; Guizard, C. In Situ X-ray Radiography and Tomography Observations of the Solidification of Aqueous Alumina Particle Suspensions-Part I: Initial Instants. J. Am. Ceram. Soc. 2009, 92, 2489-2496. [CrossRef]

(C) 2018 by the authors. Licensee MDPI, Basel, Switzerland. This article is an open access article distributed under the terms and conditions of the Creative Commons Attribution (CC BY) license (http:/ / creativecommons.org/licenses/by/4.0/). 